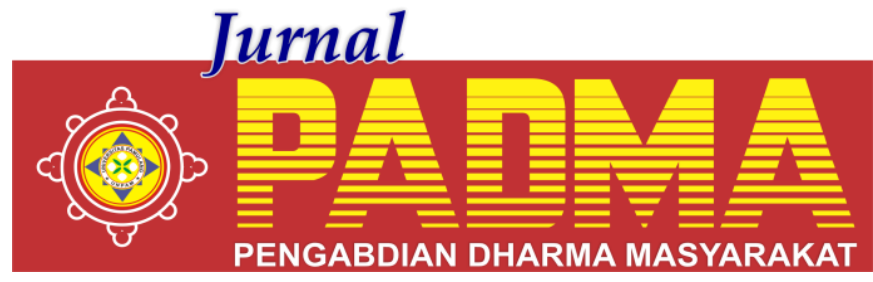

VOLUME 1, NOMOR 4, OKTOBER 2021

\title{
PENGEMBANGAN MINAT BELAJAR DITENGAH PENURUNAN NAFSU PEMBELAJARAN SELAMA DARING BERSAMA ANAK RUMAH YATIM DHUAFA AULIA
}

\author{
${ }^{1 *}$ Aprian Arpansyah Dhimas, ${ }^{2}$ Yoga Pramata ${ }^{3}$ Nadiah Herawati \\ ${ }^{4}$ Nur Hasanah, ${ }^{5}$ Rovi Rosetiani \\ Universitas Pamulang, Tangerang Selatan, Banten, Indonesia \\ *aprianepan@gmail.com
}

\begin{abstract}
Abstrak
Tujuan kegiatan Pengabdian Kepada Masyarakat (PKM) adalah untuk meningkatkan dan mengembangkan minat belajar anak - anak di tengah penurunan nafsu pembelajaran pada masa pandemi ini. Adapun metode kegiatan yang dilakukan untuk kegiatan ini adalah dengan mendatangi Rumah Yatim Dhuafa Raydha Aulia dengan maksud memberi pembelajaran dan beberapa motivasi kepada anak - anak. Lalu memberi cara dan praktek langsung untuk bagaimana mengatasi kejenuhan selama pembelajaran daring ini. Hasil dari kegiatan ini peserta jadi mempunyai motivasi dan semangat baru untuk menghadapi pembelajaran daring selama ini dengan terus mengembangkan minat belajar dan kreativitas yang sudah kami berikan pelajarannya kepada mereka, karena anak - anak sangat membutuhkan adanya perbaharuan dalam metode pembelajaran yang lebih menarik ditengah kejenuhan pembelajaran online ini.
\end{abstract}

Kata Kunci: Pembelajaran Online, Pengembangan Minat Belajar, Kreativitas

Abstract

The purpose of Community Service (PKM) is to improve and develop children's interest in learning in the middle decreased appetite for learning during this pandemic. The method of activities carried out for this activity is by visited the Dhuafa Raydha Aulia Orphanage with the intention of giving learning and some motivation to children. Then give way and hands-on practice for how to overcome boredom during learning dare. The result of this activity is that participants have motivation and enthusiasm new to facing brave learning so far continuously with develop interest in learning and creativity that we have provided the lesson to them, because children really need their updates in learning methods that are more interesting in the midst of boredom this online learning.

Keywords: Online Learning, Development of Interest in Learning, Creativity

\section{PENDAHULUAN}

Saat ini Indonesia telah dikejutkan dengan mewabahnya suatu penyakit yang disebabkan oleh sebuah virus yang bernama corona atau dikenal dengan istilah Covid-19 (Corona Virus Diseases-19). Maka dari itu, pemerintah Indonesia telah menghimbau untuk tetap di dalam rumah dan mengisolasi diri secara mandiri. Dan juga pemerintah Indonesia sudah menerapkan aturan PSBB yang merupakan singkatan dari Pembatasan Sosial Berskala Besar sejak tahun lalu yang dibuat dalam rangka penanganan Covid-19. Hal ini dilakukan dengan harapan virus tidak menyebar lebih luas dan upaya penyembuhannya dapat berjalan dengan maksimal.

Dalam usaha pembatasan sosial ini pemerintah Indonesia telah membatasi kegiatan diluar rumah seperti kegiatan pendidikan yang telah dilakukan secara online melalui pembelajaran online/daring. Pembelajaran online ini diselenggarakan melalui pemanfaatan teknologi khususnya internet. Dan juga pembelajaran online ini dilakukan dengan sistem belajar jarak jauh, dimana Kegiatan Belajar dan Mengajar (KBM) tidak dapat dilakukan secara tatap muka. Apalagi tempat pengabdian kita ini berada disebuah panti asuhan, yang mana sangat terbatasnya teknologi atau alat belajar yang 
dipunya. Maka dari itu, mereka sangat membutuhkan support atau dukungan dari masyarakat luas untuk saling bantu memudahkannya.

Menurut Departemen Sosial Republik Indonesia (DEPSOS RI) (2004:4), Panti Sosial Asuhan Anak adalah suatu lembaga usaha Kesejahteraan Sosial yang mempunyai tanggung jawab untuk memberikan pelayanan Kesejahteraan Sosial pada anak terlantar dengan melaksanakan penyantunan dan pengentasan anak terlantar, memberikan pelayanan pengganti orang tua/wali anak dalam memenuhi kebutuhan fisik, mental dan sosial kepada anak asuh sehingga memperoleh kesempatan yang luas, tepat dan memadai bagi pengembangan kepribadianya sesuai dengan yang diharapkan sebagai bagian dari generasi penerus cita- cita bangsa dan sebagai insan yang akan turut serta aktif dalam bidang pembangunan nasional.

Oleh karena itu, diperlukan adanya pendorong untuk menggerakkan minat belajar siswanya kembali agar adanya peningkatan pada semangat belajar didalam diri para siswa sehingga tetap mendapatkan prestasi yang semestinya. Yang mana dengan adanya pembelajaran online/daring dengan kebijakan baru tersebut bisa sangat memicu tingkat kemalasan atau kejenuhan anak anak dalam mengikuti pembelajaran seperti itu jika terus terusan dilakukan untuk jangka panjang.

Lalu peningkatan pembelajaran dapat dilakukan dengan menggunakan model-model pembelajaran yang sesuai dengan karakteristik mata pelajaran tertentu. Penggunaan model pembelajaran beberapa ini bisa membantu guru untuk melaksanakan pembelajaran di kelas yaitu dengan mengubah metode penyampaian materinya dengan bernyanyi dan melakukan kegiatan mewarnai untuk meningkatkan atau mengembangkan kreativitas anak.

\section{METODE}

Kegiatan Pengabdian Kepada Masyarakat ini dilaksanakan selama 1 (satu) hari yaitu pada tanggal 06 Maret 2021 di Rumah Yatim Dhuafa Raydha Aulia, Jl. Kesadaran II, Pd. Petir, Kec. Bojongsari, Depok, Jawa Barat 16517. Dengan Metode pelaksanaan yang digunakan ini adalah mendatangi rumah yatim tersebut bermaksud memberi pembelajaran dan motivasi tentang pengembangan minat belajar di tengah penurunan nafsu pembelajaran pada masa pandemi ini. Lalu juga kami melakukan beberapa games dan praktek untuk meningkatkan pengembangan minatnya, dengan cara:

1. Bernyanyi

Bernyanyi merupakan kegiatan yang penting diberikan kepada siswa, hal ini sesuai dengan karakteristik siswa. Di samping itu, sesuai dengan fungsi pembelajaran bernyanyi yang dikemukakan Rien (1999:1) bahwa bernyanyi mempunyai peranan yang penting dalam kehidupan seorang siswa. Siswa yang berpartisipasi dalam kegiatan seni musik.

Metode bernyanyi ini merupakan metode pembelajaran yang menggunakan syair-syair yang dilagukan. Biasanya syairsyair tersebut disesuaikan dengan materi yang akan diajarkan oleh pendidik. Memurut beberapa ahli, bernyanyi membuat suasana belajar menjadi riang dan bergairah sehingga perkembangan anak dapat distimmulasi secara lebih optimal. (Fadlillah, 2012:175).

2. Mewarnai

Dan menurut Hajar Pamadhi dan Evan Sukardi S. (2010:7.4) akan mengajak kepada anak bagaimana mengarahkan kebiasaan - kebiasaan anak dalam mewarnai dengan spontan menjadi kebiasaan - kebiasaan menuangkan warna yang mempunyai nilai pendidikan.

Kegiatan mewarnai juga dijadikan lingkup perkembangan kognitif yang harus dikuasai anak dengan tujuan pengasahan kemampuan imajinatif yang dapat mengembangkan kecerdasan pada anak dan menjadikan suatu kegiatan yang menyenangkan untuk anak. 


\section{HASIL DAN PEMBAHASAN}

\section{Pengertian Minat}

Minat bukanlah merupakan sesuatu yang dimiliki oleh seseorang begitu saja, melainkan merupakan sesuatu yang dapat dikembangkan. Minat yang telah ada dalam diri seseorang bukanlah ada dengan sendirinya, namun ada karena adanya pengalaman dan usaha untuk mengembangkannya.

Minat juga mengarahkan perbuatan kepada suatu tujuan dan merupakan dorongan bagi perbuatan tersebut. Dalam diri manusia terdapat dorongan dorongan (motif-motif) yang mendorong manusia untuk berinteraksi dengan dunia luar, motif menggunakan dan menyelidiki dunia luar (manipulate and exploring motives).

Maka dari itu, minat adalah suatu proses kejiwaan yang bersifat abstrak yang dinyatakan oleh seluruh keadaan aktivitas, ada objek yang dianggap bernilai sehingga diketahui dan diinginkan. Sehingga proses jiwa menimbulkan kecenderungan perasaan terhadap sesuatu, gairah atau keinginan terhadap sesuatu.

\section{Pengertian Belajar}

Menurut Witherington, sebagaimana dikutip oleh Khalijah Hasan dalam Educational Psychology mengemukakan, "Belajar adalah suatu perubahan di dalam kepribadian yang menyatakan diri sebagai suatu pola baru daripada reaksi yang berupa kecakapan sikap, kebiasaan, kepandaian, atau suatu pengertian".

Definisi yang lain sebagaimana dikemukakan oleh W.S Winkel, bahwa "Belajar adalah suatu proses mental atau psikis yang berlangsung dalam interaksi aktif subyek dengan lingkungannya dan yang menghasilkan perubahan dalam pengetahuan, pemahaman, keterampilan, nilai sikap yang bersifat konstan/menetap."

\section{Pengembangan Minat Belajar}

Minat siswa untuk belajar mempunyai pengaruh yang besar terhadap keberhasilan belajar, karena minat siswa merupakan faktor utama yang menentukan derajat keaktifan siswa, bila bahan pelajaran yang dipelajari tidak sesuai dengan minat siswa, maka siswa tidak akan belajar dengan sebaik-baiknya, sebab tidak ada daya tarik baginya.

Minat belajar adalah aspek psikologi seseorang yang menampakkan diri dalam beberapa gejala, seperti: gairah, keinginan, perasaan suka untuk melakukan proses perubahan tingkah laku melalui berbagai kegiatan yang meliputi mencari pengetahuan dan pengalaman.

Dengan kata lain, minat belajar itu adalah perhatian, rasa suka, ketertarikan seseorang (siswa) terhadap aktivitas belajar yang ditunjukkan melalui keantusiasan, partisipasi, dan keaktifan dalam belajar serta menyadari pentingnya kegiatan itu.

Apalagi ditambah pada suasana pandemi ini, anak - anak makin merasa sangat bosan dan jenuh dengan semua pembelajaran online/daring yang menyebabkan penurunan nafsu pembelajaran pada setiap masing - masing siswa dikarenakan beberapa faktor yang ada, jadi diperlukanlah pembaharuan dan pengembangan pada metode belajarnya dalam melaksanakan pembelajaran untuk mengatasi masalah tersebut.

\section{PENUTUP}

Anak-anak dalam berbagai umur pada dasarnya senang mendengarkan, menyanyikan, dan belajar dengan nyanyian/lagu. Oleh karena itu musik secara umum merupakan bagian penting dari proses belajar - mengajar bagi anak - anak. Hampir semua bentuk nyanyian dari yang tradisional sampai dengan yang pop dapat dimanfaatkan oleh guru dalam pembelajaran. Maka dari itu, kita menggunakan teknik tersebut sebagai awal cara pembelajarannya untuk membangkitkan suasana atau efouria yang menyenangkan terlebih dahulu ditengah penurunan nafsu minat belajar mereka.

Lalu teknik perencanaan pembelajaran selanjutnya dilakukan guru khususnya dalam kegiatan pembelajaran bisa melalui cara mewarnai sebuah gambar, yang juga harus 
sesuai dengan aspek yang akan ditingkatkan pada anak. Dengan pembelajaran mewarnai gambar, ini juga dapat meningkatkan kemampuan motorik halus pada anak - anak dengan teknik pemilihan warna, pencampuran antara warna satu dengan yang lain atau juga penambahan warna objek yang bervariasi.

Pada pembelajaran online, para siswa atau anak - anak dapat menjadi kurang aktif dalam menyampaikan aspirasi dan pemikirannya, sehingga dapat mengakibatkan pembelajaran yang menjenuhkan. Maka di dalam kondisi yang serba terbatas saat ini, dibutuhkan pemahaman dan kreativitas guru dalam mengemas pembelajaran onlinenya agar menarik perhatian dan motivasi siswa dalam mengikuti tahapan pembelajaran online. Pemilihan pendekatan dan model pendekatan yang tepat, serta dukungan berbagai pihak dapat menjadi penentu keberhasilan pembelajaran online.

\section{DAFTAR PUSTAKA}

Desyandri, S.Pd.,M.Pd. (2011). Pembelajaran Bernyanyi dengan Menggunakan Model Pembelajaran Langsung (Explicit Instruction). Desyandri wordpress. Padang.

Elvania Rachim. (2020). Hubungan Pelaksanaan Pembelajaran Daring Dengan Minat Belajar Siswa Mi Pada Masa Pandemi Covid- 19 Di Desa Krincing Secang Magelang. Institut Agama Islam Negeri Salatiga.

Khoiri, A., et al. (2021, February). 4Cs Analysis of 21st Century Skills-Based School Areas. In Journal of Physics: Conference Series (Vol. 1764, No. 1, p. 012142). IOP Publishing.
Mona, N. (2020). Konsep Isolasi Dalam Jaringan Sosial Untuk Meminimalisasi Efek Contagious (Kasus Penyebaran Virus Corona Di Indonesia). Jurnal Sosial Humaniora Terapan Universitas Indonesia, 2(2).

Nieta Meylinie. Pembelajaran Mewarnai Gambar Untuk Meningkatkan Kemampuan Motorik Halus Pada Anak Usia 5-6 Tahun. Universitas Tanjungpura. Pontianak.

Paeno, P., et al. (2020). Pemanfaatan Sampah Plastik Untuk Kerajinan Rumah Tangga Taman Belajar Kreatif Mekar Sari. BAKTIMAS: Jurnal Pengabdian pada Masyarakat, 2(1), 57-61.

Ria Yunitasari dan Umi Hanifah. (2020). Pengaruh Pembelajaran Daring terhadap Minat Belajar Siswa pada Masa COVID-19. Jurnal Ilmu Pendidikan. Volume 2 Nomor 3 Tahun 2020 Halm 232 - 243. Surabaya.

Ridwan dan A.Fajar Awaluddin. (2019). Penerapan Metode Bernyanyi Dalam Meningkatkan Penguasaan Mufradat Dalam Pembelajaran Bahasa Arab Di Raodhatul Athfal. Jurnal Kependidikan, Vol. 13 No. 1 Juni 2019. Sekolah Tinggi Agama Islam Al-Gazali Bone. Sulawesi Selatan.

Sunarsi, D. (2018). Analisis Motivasi Kerja Tenaga Pendidik Sukarela Pada Pusat Kegiatan Belajar Masyarakat (PKBM) Bimasda Kota Tangerang Selatan. Kreatif: Jurnal Ilmiah Prodi Manajemen Universitas Pamulang, 6(2), 53-65.

Ubaidillah. (2019). Pengembangan Minat Belajar Kognitif Pada Anak Usia Dini. Journal of Childhood Education. Vol. 3 No. 1 Tahun 2019. Hal. 58 - 85, 26203278 (E-ISSN), 2598-2184 (P-ISSN). 